SHORT COMUNICATION

\title{
A Multiplex-PCR Approach to Identification of the Brazilian Intermediate Hosts of Schistosoma mansoni
}

\author{
THDA Vidigal/*, KG Magalhães*, JC Kissinger**, RL Caldeira*, AJG Simpson***, \\ OS Carvalho ${ }^{* /+}$
}

\begin{abstract}
Departamento de Zoologia, Instituto de Ciências Biológicas, UFMG, Belo Horizonte, MG, Brasil *Centro de Pesquisas René Rachou-Fiocruz, Av. Augusto de Lima 1715, 30190-002 Belo Horizonte, MG, Brasil **Department of Biology, University of

Pensylvania, Philadelphia, PA, USA ***Laboratório de Genética do Câncer, Instituto Ludwig de Pesquisa sobre o Câncer,
\end{abstract} São Paulo, SP, Brasil

Due to difficulties concerning morphological identification of planorbid snails of the genus Biomphalaria, and given a high variation of characters and in the organs with muscular tissue, we designed specific polymerase chain reaction (PCR) primers for Brazilian snail hosts of Schistosoma mansoni from available sequences of internal transcribed spacer 2 (ITS2) of the ribosomal RNA gene. From the previous sequencing of the ITS2 region, one primer was designed to anchor in the 5.8S conserved region and three other species-specific primers in the $28 S$ region, flanking the ITS2 region. These four primers were simultaneously used in the same reaction (MultiplexPCR), under high stringency conditions. Amplification of the ITS2 region of Biomphalaria snails produced distinct profiles (between 280 and $350 \mathrm{bp}$ ) for B. glabrata, B. tenagophila and B. straminea. The present study demonstrates that Multiplex-PCR of ITS2-DNAr showed to be a promising auxiliary tool for the morphological identification of Biomphalaria snails, the intermediate hosts of S. mansoni.

Key words: Biomphalaria - Multiplex-PCR - internal transcribed spacer 2

Morphological identification of planorbids of the genus Biomphalaria, the intermediate hosts of Schistosoma mansoni, is based on a comparison of the characters of shell, genital and excretory systems described by Paraense $(1975,1981,1984,1988)$. However, this identification becomes difficult due to the high variation of such characters and in the organs with muscular tissue, because of its distension at the fixing moment (Paraense 1975). Paraense (1966) remarks that, due to the different environments occupied by some species, they show a high morphological intraspecific variation. Other species such as $B$. straminea, $B$. kuhniana and $B$. intermedia have very few morphological differences regarding the genital system, making their distinction difficult (Paraense 1988, Caldeira et al. 1998).

Relevant advancements have occurred in the field of molluskans systematics. A remarkable change was the introduction of molecular techniques. Molecular systematics may approach several problems considered insoluble by traditional methodologies. Vidigal et al. (1996), using low stringency polymerase chain reaction (LS-PCR) technique, were able to differentiate $B$. glabrata and $B$. tenagophila. Pires et al. (1997), using the same technique,

Work partially supported by Fapemig and Pibic/Fiocruz. ${ }^{+}$Corresponding author. Fax: + 55-31-3295.3115. E-mail: omar@cpqrr.fiocruz.br

Received 18 June 2002

Accepted 15 August 2002 differentiated B. tenagophila from B. occidentalis. Vidigal et al. (1998) used PCR and restriction fragment length polymorphism (PCR-RFLP) technique for the internal transcribed spacer (ITS) region (rDNA) analysis, which included ITS1 + 5.8S + ITS2, to differentiate these three Brazilian intermediate hosts species of S. mansoni. Caldeira et al. (1998) used the same methodology to differentiate $B$. straminea, $B$. intermedia, $B$. kuhniana and $B$. peregrina and Spatz et al. (1999) to distinguish $B$. tenagophila, B. t. guaibensis and B. occidentalis.

The Multiplex-PCR technique consists in using specific primers, simultaneously, under high stringency conditions. It has been used for the identification of several organisms such as fungal strains, free-living protozoon and some viruses (Fujita et al. 2001, Mosquera et al. 2002, Manguin et al. 2002, Pelandakis \& Pernin 2002).

The present study was aimed at designing specific primers for Brazilian snail hosts of $S$. mansoni from available sequences of ITS2 of the ribosomal RNA gene, sequenced by Vidigal et al. (2000a), for phylogenetic studies on Brazilian Biomphalaria.

Studies were undertaken using snails, from different Brazilian localities, of the species B. glabrata (from Pará, Sergipe, Minas Gerias), B. tenagophila (from Goiás, Minas Gerais, Espírito Santo) and B. straminea (from Piauí, Bahia, Rio Grande do Sul). The snails were killed and the foot of each specimen was removed for DNA extraction. Afterwards, they were morphologically identified, according to Paraense $(1975,1981,1984,1988)$. Total DNA was extracted from each snail's foot using the Wizard kit (Promega), as described by Vidigal et al. (2000b). From previous sequencing of the ITS2 region, one primer (ITS2f) 
was designed to anchor in the $5.8 \mathrm{~S}$ conserved region and three other species-specific primers (BgIITS2r, BtenITS2r and BstITS2r) anchored in the $28 \mathrm{~S}$ region, flanking the ITS2 region. These four primers were simultaneously, under high stringency conditions (Multiplex-PCR). PCR amplification was undertaken in a volume of $10 \mu$, with 1 ng template DNA, 5 pmol of each primer, $200 \mu \mathrm{M}$ each dNTP (dNTP- PROMEGA), $0.8 \mathrm{U}$ of Taq DNA polymerase, in a buffer solution of $10 \mathrm{mM}$ Tris- $\mathrm{HCl}, \mathrm{pH} 8.5,50 \mathrm{mM} \mathrm{KCl}$, $1.5 \mathrm{mM} \mathrm{MgCl}$. The reactions were covered with a drop of mineral oil and subjected to the following cycle program: initial denaturation step for $3 \mathrm{~min}$ at $95^{\circ} \mathrm{C}$ and then 24 cycles for annealing at $60^{\circ} \mathrm{C}$ for $1 \mathrm{~min}$ and extension at $72^{\circ} \mathrm{C}$ for $5 \mathrm{~min}$. A negative control (no DNA) was included in all the experiments. PCR products were visualized in $6 \%$ silver stained polyacrylamide gels.

The amplification of the ITS2 region of Biomphalaria snails produced distinct fragments (between 280 and 350 bp): B. glabrata (280 bp), B. tenagophila ( $320 \mathrm{bp})$ and $B$. straminea $(350 \mathrm{bp}$ ) (Figure) from the localities, mentioned above. Thus, the reproducibility of the obtained profiles was supported by use of Biomphalaria snails from distinct localities, in Brazil, and by increasing number of specimens (3) used (data not shown). The present study demonstrates that Multiplex-PCR of the ITS2-DNAr showed to be a promising auxiliary tool for the morphological identification of Biomphalaria snails, intermediate hosts of $S$. mansoni. This assay offers a rapid, simple and feasible identification method for these mollusks. It could be systematically applied as a diagnostic test in epidemiological studies, and afterwards in control measures against the expansion of schistosomiasis. We believe that this methodology may be reliably employed in the identification of these planorbids. In addition, it will be possible to assess the specificity of the designed primers for the ITS2 region, concerning other Biomphalaria species, especially B. straminea (Paraense 1988) and B. tenagophila (Spatz et al. 1999) complex.

\section{ACKNOWLEDGEMENTS}

To Dr Liana K Passos from Centro de Pesquias René Rachou, who provided valuable critical comments.

\section{REFERENCES}

Caldeira RL, Vidigal THDA, Paulinelli ST, Simpson AJG, Carvalho OS 1998. Molecular identification of similar species of the genus Biomphalaria (Mollusca: Planorbidae) determined by PCR-RFLP. Mem Inst Oswaldo Cruz 93: 219-225.

Fujita SI, Senda Y, Nakaguchi S, Hashimoto T 2001. Multiplex PCR using internal transcribed spacer 1 and 2 regions for rapid detection and identification of yeast strains. J Clin Microbiol 39: 3617-3622.

Manguin S, Kengne P, Sonnier L, Harbach RE, Baimai V, Trung HD, Coosemans M 2002. SCAR markers and multiplex PCR based identification of isomorphic species in the Anopheles dirus complex in Southeast Asia. Med Vet Entomol 16: 46-54.

Mosquera MD, Ory F, Moreno M, Echevarria JE 2002. Simultaneous detection od measles virus, rubella virus, and parvovirus B19 by using multiplex PCR. J Clin Microbiol 40: 111-116.

Paraense WL 1966. Biomphalaria amazonica and B. cousini, two new species of neotropical planorbid molluscs. Rev

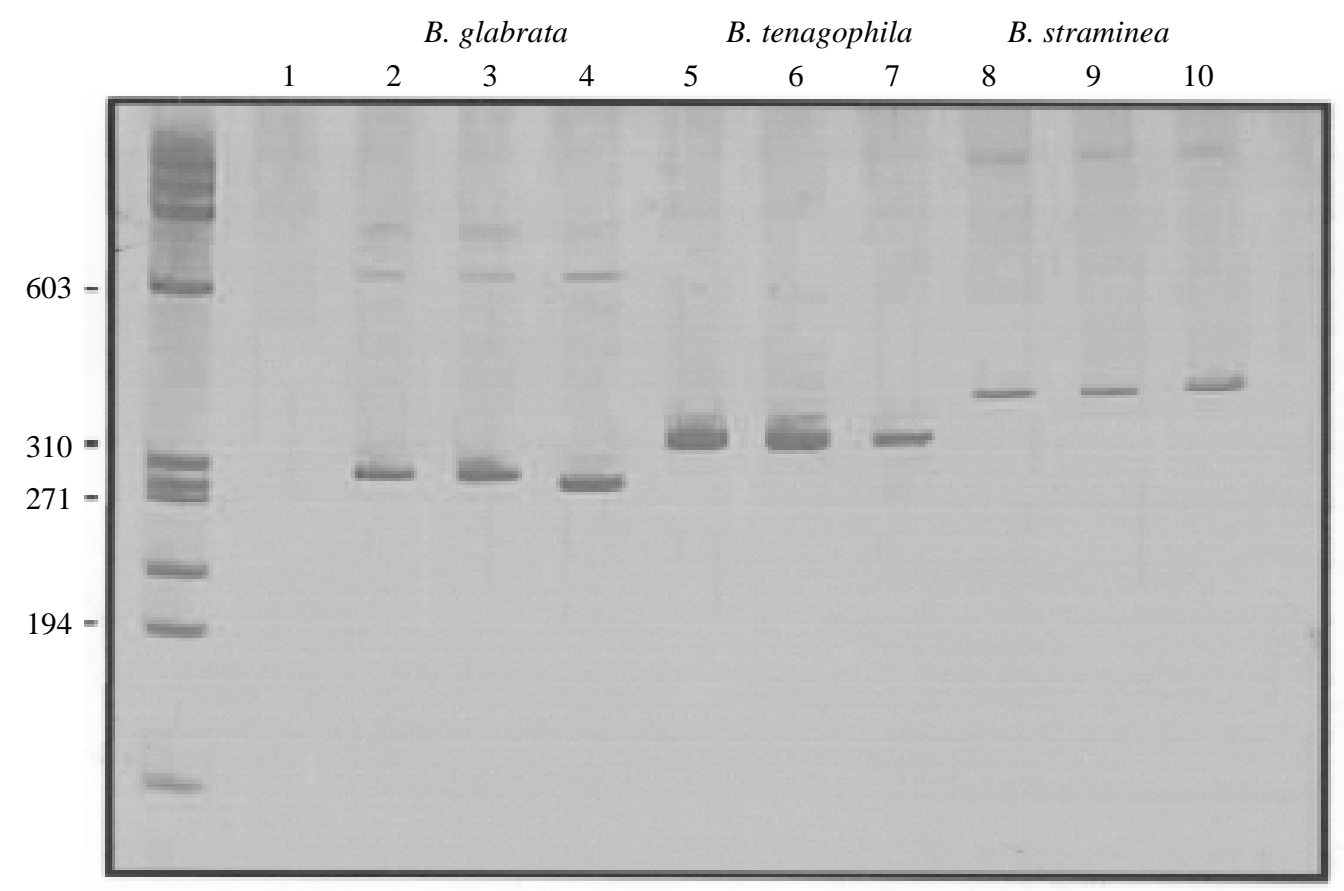

6\% silver stained polyacrylamide gel showing the Multiplex-PCR amplification of the internal transcribed spacer 2 regions of the Brazilian intermediate hosts of Schistosoma mansoni. Lanes - 1: negative control (no DNA added); 2: Biomphalaria glabrata from Belém, Pará; 3: B. glabrata from, Aracajú, Sergipe; 4: B. glabrata from Sabará, Minas Gerais; 5: B. tenagophila, from Formosa, Goiás; 6: B. tenagophila from Vespasiano, Minas Gerais; 7: B. tenagophila, from, Vitória, Espírito Santo; 8: B. straminea from Picos, Piauí; 9: B. straminea from Várzea do Poço, Bahia; 10: B. straminea from Porto Alegre, Rio Grande do Sul; molecular size markers are shown on the left of the gel. 
Bras Biol 26: 115-116.

Paraense WL 1975. Estado atual da sistemática dos planorbídeos brasileiros. Arq Mus Nac Rio de Janeiro 55: 105-128.

Paraense WL 1981. Biomphalaria occidentalis sp.n. from South America (Mollusca, Basommatophora, Pulmonata). Mem Inst Oswaldo Cruz, 76: 199-211.

Paraense WL 1984. Biomphalaria tenagophila guaibensis sp.n. from Southern Brazil and Uruguay (Pulmonata: Planorbidae). I. Morphology. Mem Inst Oswaldo Cruz 79: 465-469.

Paraense WL 1988. Biomphalaria kuhniana (Clessin, 1883), planorbid mollusc from South America. Mem Inst Oswaldo Cruz 83: 1-12.

Pelandakis M, Pernin P 2002. Use of multiplex PCR and PCR restriction enzyme analysis for detection and exploration of the variability in the free-living amoeba Naegleria in the environment. Appl Environ Microbiol 68: 2061-2065.

Pires ER, Vidigal THDA, Teles HMS, Simpson AJG, Carvalho OS 1997. Specific identification of Biomphalaria tenagophila and Biomphalaria occidentalis populations by the low stringency polymerase chain reaction. Mem Inst Oswaldo Cruz 92: 101-106.

Spatz L, Vidigal THDA, Caldeira RL, Dias Neto E, Cappa SMG, Carvalho OS 1999. Study of Biomphalaria tenagophila, B. t. guaibensis and B. occidentalis by poly- merase chain reaction amplification and restriction enzyme digestion of the ribosomal RNA gene intergenic spacer. $J$ Moll Stud 65: 143-149.

Vidigal THDA, Caldeira RL, Simpson AJ, Carvalho OS 2000b. Further studies on the molecular systematics of Biomphalaria snails from Brazil. Mem Inst Oswaldo Cruz 95: 57-66.

Vidigal THDA, Dias Neto E, Simpson AJG, Carvalho OS 1996. A low stringency polymerase chain reaction approach to identification of Biomphalaria glabrata and Biomphalaria tenagophila intermediate snail hosts of Schistosoma mansoni in Brazil. Mem Inst Oswaldo Cruz 91: 739-744.

Vidigal THDA, Kissinger JC, Caldeira RL, Pires EC, Monteiro E, Simpson AJ, Carvalho OS 2000a. Phylogenetic relationships among Brazilian Biomphalaria species (Mollusca: Planorbidae) based upon analysis of ribosomal ITS2 sequences. Parasitology 121: 611-620.

Vidigal THDA, Spatz L, Nunes DN, Simpson AJG, Carvalho OS, Dias Neto E 1998. Biomphalaria spp: identification of the intermediate snail hosts of Schistosoma mansoni by polymerase chain reaction amplification and restriction enzyme digestion of the ribossomal RNA gene intergenic spacer. Exp Parasitol 89: 180-187. 
98 Multiplex-PCR to Identification of Biomphalaria sp. - Teofânia Vidigal et al. 